\title{
Impact Orientation in Austria
}

\section{Benedikt SPEER ${ }^{1}$ \\ Kathrin WINKLER ${ }^{2}$}

\begin{abstract}
The implementation of impact orientation within the public sector constitutes an en-tirely new approach of governance. Until recently - and in many cases still so - public administration was primarily input-oriented, which means focusing on the resources (financial, personnel etc.) needed to fulfil existing public tasks instead of focusing on the results and final effects which are intended to be reached ultimately by these often long ago defined assignments. As experience shows, the pressing challenge of increasing steadily the effectiveness and efficiency within public administration cannot be reached by such a one-sided and consequently limited approach. Thus, a wider and more comprehensive concept is necessary to optimize the public sector in all its dimensions. As a result of prevalent budget crises, increasing pressure of stakeholders towards public administration and generally less room for manoeuver due to a growing regulatory burden, new/adapted and more flexible ways of thinking and acting within the public sector are required. Hence, modern concepts of steering and control - not only in Europe but in a larger number of OECD countries - now tend to give more importance to the targets and effects of public administration and its activities within the societal context. This rather new concept - the so called "impact orientation" which has been introduced in Austria as core element of the Federal Budget Law Reform 2009/2013 - requires a fundamental alignment of governmental actions and a new focus on the outputs and even on the outcomes of political and administrative strategies. The results until now have been primarily "outwardly-oriented" reform concepts concentrating on the external societal effects of politico-administrative actions. However, recent research results show for Austria, that this external dimension has to be linked more closely with internal reform efforts and internal impact targets in order to unfold its benefits in a holistic way.
\end{abstract}

${ }^{1}$ FH-Prof. MMag. Dr. Benedikt Speer (CUAS; Austria), b.speer@fh-kaernten.at

${ }^{2}$ Kathrin Winkler, BA MA (CUAS; Austria), k.winkler@fh-kaernten.at 


\section{Impact Orientation in Austria: Reform Pillars and Elements}

In Austria, the federal government introduced impact orientation as a core part of the two-step reform of the Federal Budget Law 2009/2013. It has to be assumed that when this reform was unanimously adopted by parliament in 2007 , most members - as well as most civil servants, apart from some very astute and high-ranking reform promotors mainly in the Ministry of Finance - had no clear idea about the real scope of the planned reform. The proclaimed goals fitted nicely into the all too well-known and widespread reform rhetoric: to overcome the traditional input orientation of budgetary and administrative management; to emphasize the output and particularly the intended outcomes of public policies; and to implement special mechanisms to measure the reform results. The basic elements of the new model are described in figure 1:

Figure 1: Impact Model ${ }^{3}$

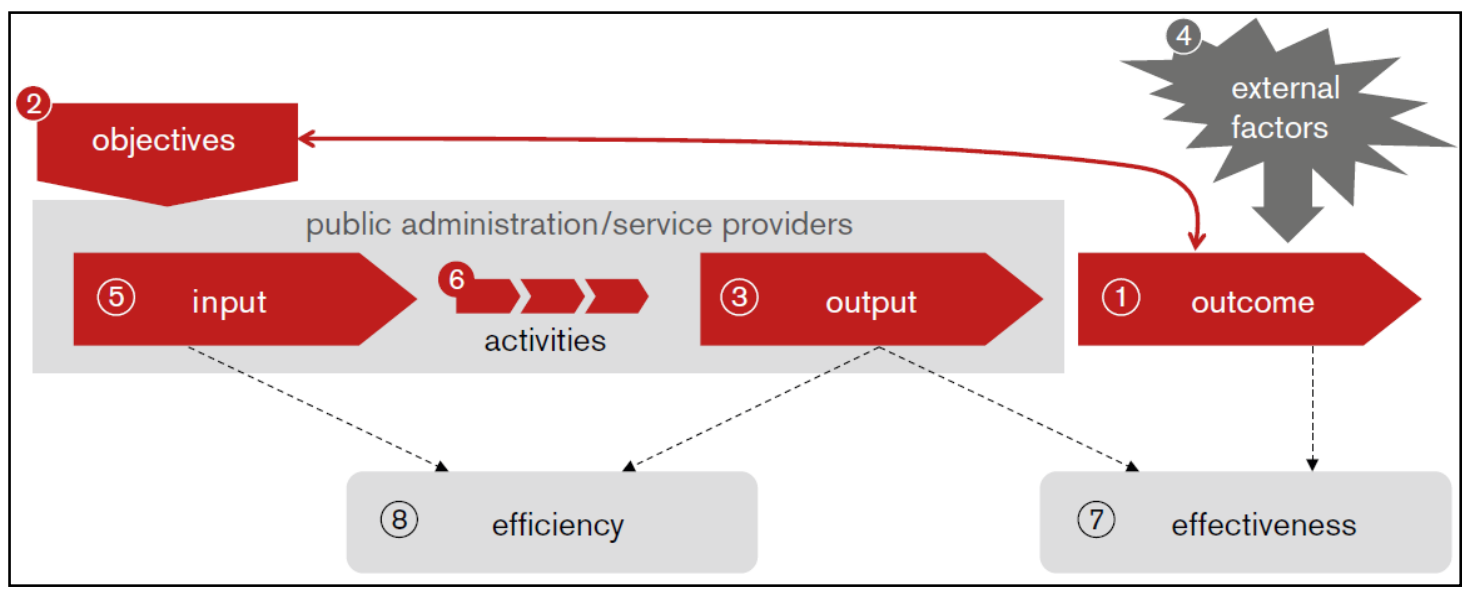

Based on the overall political strategies the expected and defined effects/outcomes (1) are cast in concrete objectives (2). These have to be operationalized by public admin-istration in form of specific outputs and measures (3). To quantify and scale the outcome and results, corresponding impact indicators have to be defined; however, unpredictable external effects (4) can always influence the outcome. Contrary to the traditional input-orientation, the allocation of resources - the input (5) - follows only as the last step within the functional chain. This new management model should finally allow for a higher input and output efficiency (8) and thus for an enhanced effectiveness of public actions (7).

\footnotetext{
${ }^{3}$ Adapted from Federal Chancellery, 2012a, p. 3.
} 


\subsection{The Federal Budget Law Reform and Impact Orientation}

When the reform of the Federal Budget Law 2009/2013 was prepared in detail and finally entered into force, it was based on three closely intertwined pillars:

- the so-called "Impact Oriented Administrative Management" as the overall management philosophy and the framework for a new political and administrative culture;

- the "Impact Oriented Financial Management", that intends a more flexible allocation of funds and budgetary steering/control;

- the "Impact Oriented Regulatory Assessment" including the (internal) evaluation of the governmental legislation and its effects.

The legal core elements which link these three pillars are:

- the medium term (4 years) and the annual budget planning;

- the steering and control of budget positions based on the principles of impact orientation;

- the ongoing general reporting and information;

- the final impact oriented controlling and assessment.

The nucleus of the Austrian impact orientation model, therefore, is the implementation within the national budget process as shown in figure 2:

Figure 2: Budget-, Target- and Performance Hierarchy 4

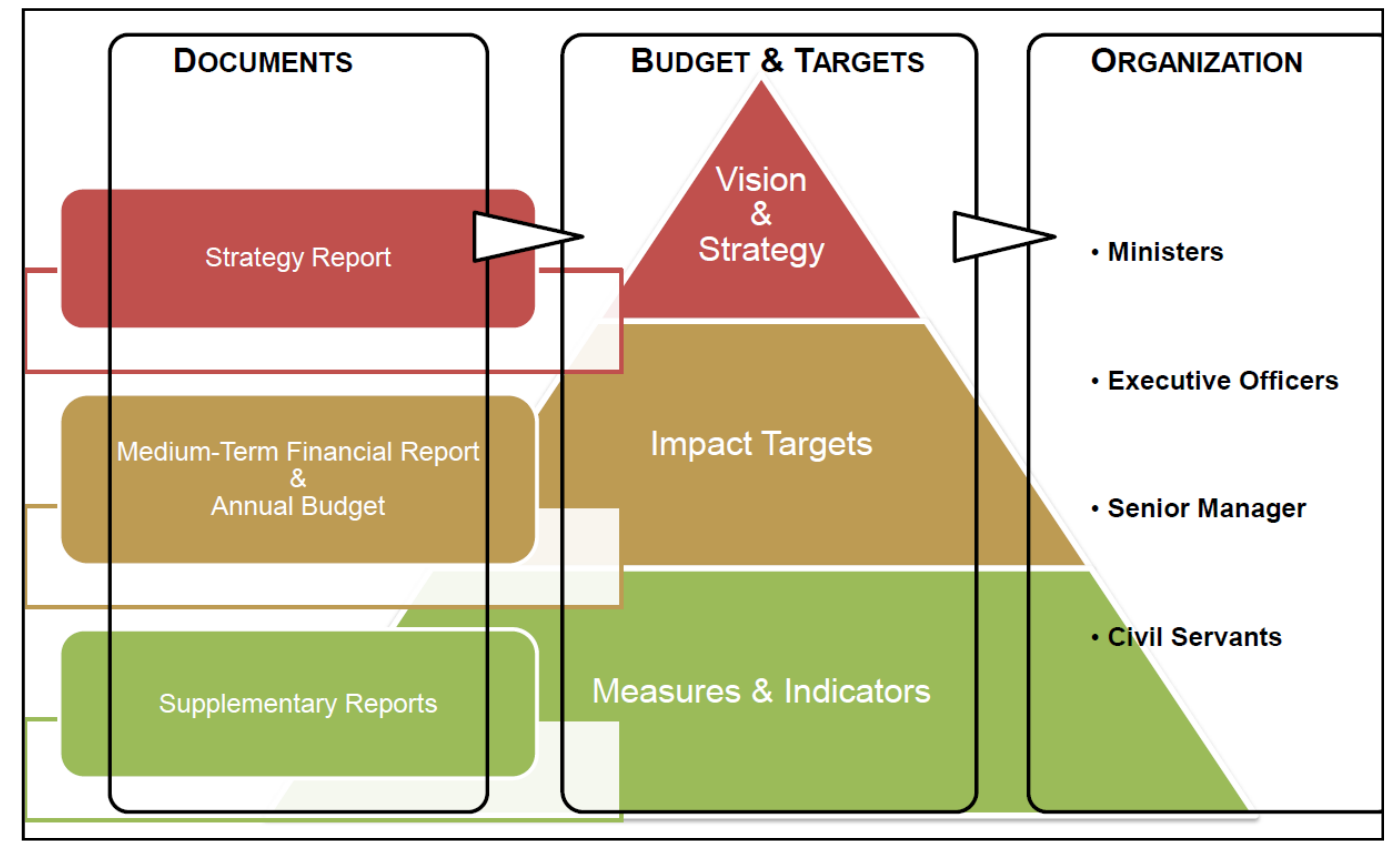

\footnotetext{
4 Source: Authors.
} 
To harmonize the available resources with the political priorities and the strategic planning it is not only necessary to adjust the budgetary process, but also the documentary and organizational structures. On the basis of the newly introduced "Budget-, Target- and Performance Hierarchy" the connection of the budget (at all budgetary levels) with the priorities, aims and measures of politics is assured. This approach extends top down across all administrative levels and is indispensable as an interface between the "Impact Oriented Administrative Management", the "Impact Oriented Financial Management" and the "Impact Oriented Regulatory Assessment".

\subsection{The Performance Management Cycle}

It has not been overseen, but perhaps underestimated that the new budget structure would also consequently demand a new, impact oriented management philosophy and culture encompassing the entire structure of the federal administration. Its most visible and tangible result is the so-called "Performance Management Cycle" as shown in figure 3 :

Figure 3: Performance Management $\mathrm{Cycle}^{5}$

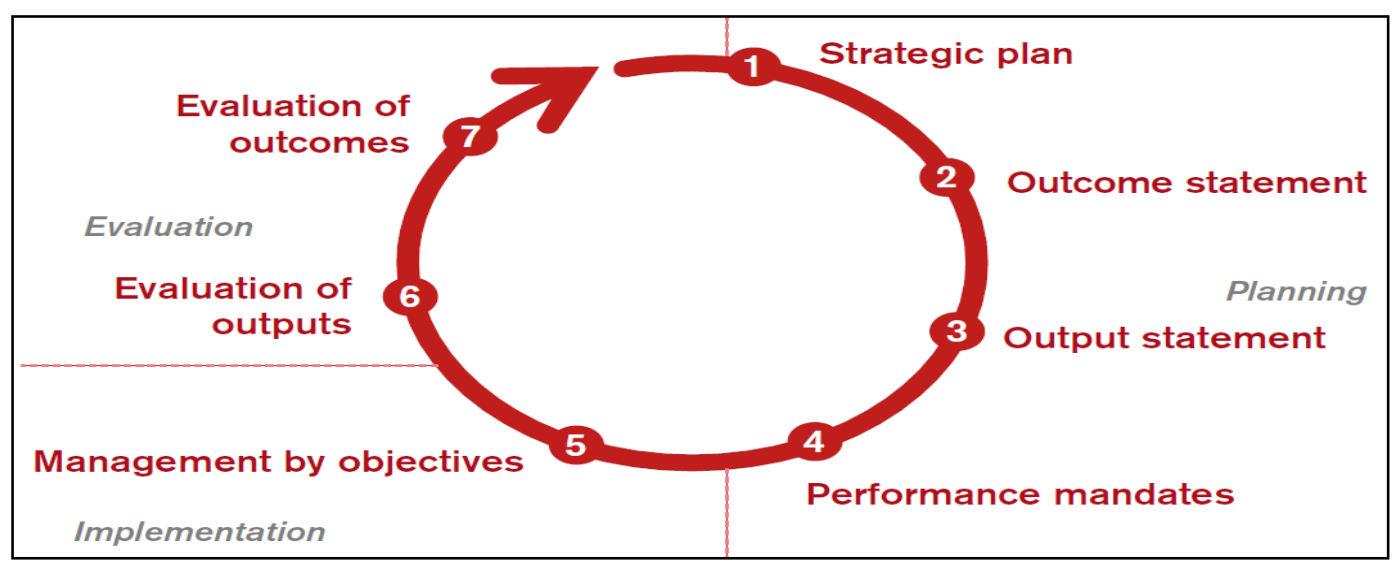

The "Performance Management Cycle" is directly oriented towards the budgetary pro-cess. The new Federal Budget Law requires the definition of intended outcomes and corresponding aims and measures at all levels of the political-administrative system as

${ }^{5}$ Adapted from Federal Chancellery, 2012a, p. 4. 
the basis for the planning, implementation and evaluation of public actions. The planning phase initially demands a multi-annual strategic plan (1) of each Ministry and each Supreme State Organ that is laid down in the Strategy Report for the Medium-Term (4 years) Expenditure Framework. This broad strategy is specified for each financial year in the annual Federal Budget, by means of outcome (2) and output statements (3). There is a clear distinction, at least in theory, between outcome statements - focusing on the intended effects to be reached in society - and output statements - referring to the priorities to be set and the measures to be taken by public administration in order to realize and achieve the defined outcomes. In sum, the outcome and output statements should provide orientation for Parliament and the interested public regarding the political priorities to be pursued by the respective Ministry or other public bodies in the next financial year and their linkage to concrete administrative actions. In other words: they reveal the underlying political reasons for the allocation of public funds and their use by public administrations.

Within public administration, the adaption and implementation of these overall priori-ties is ensured by means of performance mandates (4). These constitute the operative medium-term work plan for an administrative unit over the next four years.

On the one hand, this approach allows the definition and operational sharpening of particular policy targets at different levels with the necessary transparency; on the other hand it attempts to ensure their practical achievement through the so-called "Management by Objectives" (5). One key element in this context, which is often neglected, is the integration of all these aspects in the individual appraisal interviews for each civil servant in order to clarify his or her contribution to reach the defined targets of each sub-unit and the administrative organization as a whole.

To be able to steer and to control effectively, it is most important to regularly evaluate (6) the output in a first step to discover possible deviations from the plan immediately and to correct them. In a second step, the additional evaluation of the outcome (7) is required in order to recognize whether the intended effects have been achieved or not. In case of deviation, explanations have to be given and corrections have to be un-dertaken. These evaluation results should be carefully taken into account for the elabo-ration of the next strategic plan, as they do not merely show concrete shortcomings but also possible potentials for the improvement of public actions and the 
respective organi-zational contributions. Thus, the "Performance Management Cycle"becomes efficacious.

\subsection{Advantages of Impact Orientation for Main Stakeholders}

Theoretically, impact orientation as a new management model should provide benefits for all relevant stakeholders: Members of Parliament, Ministers, the administration and the informed/interested public in general. In particular, the amelioration of the parliamentary budget and control mechanisms have been emphasized, as Members of Parliament are now better informed due to the greater transparency of the political planning (strategic) and administrative implementation (operative). They are in a better position to demand that government and public administration achieve the set objectives, which is an essential prerequisite to the effective management of taxpayers' money.

Ministers can specify and justify political priorities, which is or at least could be especially in times of financial crisis - also a way to ultimately legitimate necessary cutbacks in other areas of minor importance. Of course, the "danger" of being held responsible for the failure of reaching given targets is evident, but in the "Realverfassung" (approximately: the de facto functioning of the Austrian legal and political system) this danger seems until now to be rather negligible. While the necessary efforts to define, legitimize, and finally "sell" the success of the own political agenda are now certainly greater than before, a Minister can also use the new system in order to positively accentuate his or her own political profile.

Public administration, in turn, has the possibility to clearly show the range of services provided for citizens, interest groups, politicians and other stakeholders. After years of successive general cutbacks, the definition of concrete priorities and targets might also serve as a justification for the re-allocation of funds and personnel in order to be able to fulfil the politically defined tasks. As administration is often perceived as a more or less mute "service institution" and a pawn in the hands of politics, the constant interaction with the political level that is a demand of impact orientation could also enhance the mutual appreciation of the functioning and the needs of both sides and thus result in a more objective approach towards administration in general and administrative reforms in particular. 
Last but not least, civil society - or rather informed and interested parts of it can gain a better understanding of political processes and administrative performances. Ideally, this will strengthen public participation and involvement in political affairs. As gender diversity aspects have to be included obligatorily in the formulation of impact targets, impact orientation should also foster the constitutionally guaranteed equality of women and men by showing, analyzing and controlling the different effects of government activities in this field.

\section{Impact Orientation: First Results And Adaptational Needs}

After the obligatory implementation of impact orientation at the federal level in 2013 first evaluations, resulting adaptational needs but also first spill-over effects have be-come visible.

\section{$2.1 \quad$ Evaluations and Results}

As should have been expected regarding the scope of this reform, a huge number of difficulties and obstacles have been discovered in the first cycle of the Austrian approach to impact orientation. Although the legal and technical aspects have been meticulously developed, already the specification of and the causal relationships be-tween impacts, objectives, measures and indicators have proven to be extremely challenging in the planning and implementation process. Not only the quality of the measures themselves but also the sheer quantity of the demanded and produced data have led to deep dissatisfaction. As a result, the budget - against the original intentions - has not yet been used as an instrument of steering and control, but still remains more or less an informational tool for the parliament and a way to justify the necessity of public expenses for politicians. This justification is all the more facilitated, as the relation between causes and effects is hardly reliable due to a multitude of possible influencing variables, external effects and time-lags. All in all, the Austrian concept itself turns out to be too formalistic and technocratic, so that the cost-benefit equation is questionable - at least in the short term perspective. Furthermore, the persistence of traditional organizational and behavioral structures still constantly collides with the logic of the new management and steering philosophy. Above all, a lack of horizontal and vertical coordination and harmonization mechanisms in the Austrian constitutional and political 
sys-tem does not allow for the effective implementation of an overall strategy and still less for an alignment between all territorial authorities within the country.

\section{$2.2 \quad$ Adaptations}

Based on the evaluation results first adaptational needs are discussed - mainly in small circles of directly involved "insiders". One step will be the cutting-back of the informational requirements, while at the same time a better and more functional information system (web-based) is introduced. Another crucial point, still heavily disputed, will be the prerogative of the interpretation and assessment of impact targets, which is contested between the Federal Chancellery, the Finance Ministry, the Budget Board of the Parliament and the Supreme Audit Court. Nevertheless, in the long run the real chal-lenge will be the harmonization of the budgetary and organizational logics with the phi-losophy of impact orientation and thus - as in other ambitious reform projects the re-alization of a cultural change in the political and administrative system.

\section{Spill-Over And Perspectives}

Despite the existing problems, impact orientation in Austria seems to be hardly revisable. First of all, it is now constitutionally secured and most experts discuss reform needs but not the abolition of the system. Several of the nine federal states of Austria have already declared their intentions to implement the new management concept, even if the state of development is still remarkably diverse. All the more it should be highlighted, that several district commissions - forming the territorial administration of the federal states - have joined on a voluntary basis to proactively define impact targets, measures and indicators for selected service areas in their field of competence:

- employee orientation (internal)

- citizen orientation (external)

- needs-based minimum benefit system (social).

This exceptional attempt - until now peerless in Austria - is scientifically accompanied by the Public Management Department of Carinthia University of Applied 
Sciences (CUAS). One result, which has already gained recognition also at the Federal level, has been the realization, that the predominating understanding of impact orientation in Austria has been until now too narrow in its emphasis on external societal effects. On the contrary, it is imperative that the external perspective is complemented by internal impact targets, which have to involve directly the civil servants responsible for understanding, applying, documenting and finally evaluating the new management concept.

Without taking into account the necessity to additionally define and implement internal impact targets, the new reform will possibly follow the example of the now rather old "New Public Management": a sophisticated, technically highly developed management model, which finally could not be brought to life due to the widespread negligence of the human factor as a crucial reform variable. For a holistic approach towards impact orientation it is, thus, compulsory to combine and interlink internal and external impact targets, measures and indicators as shown in figure 4:

Figure 4: Adapted Impact Model -Holistic Approach ${ }^{6}$

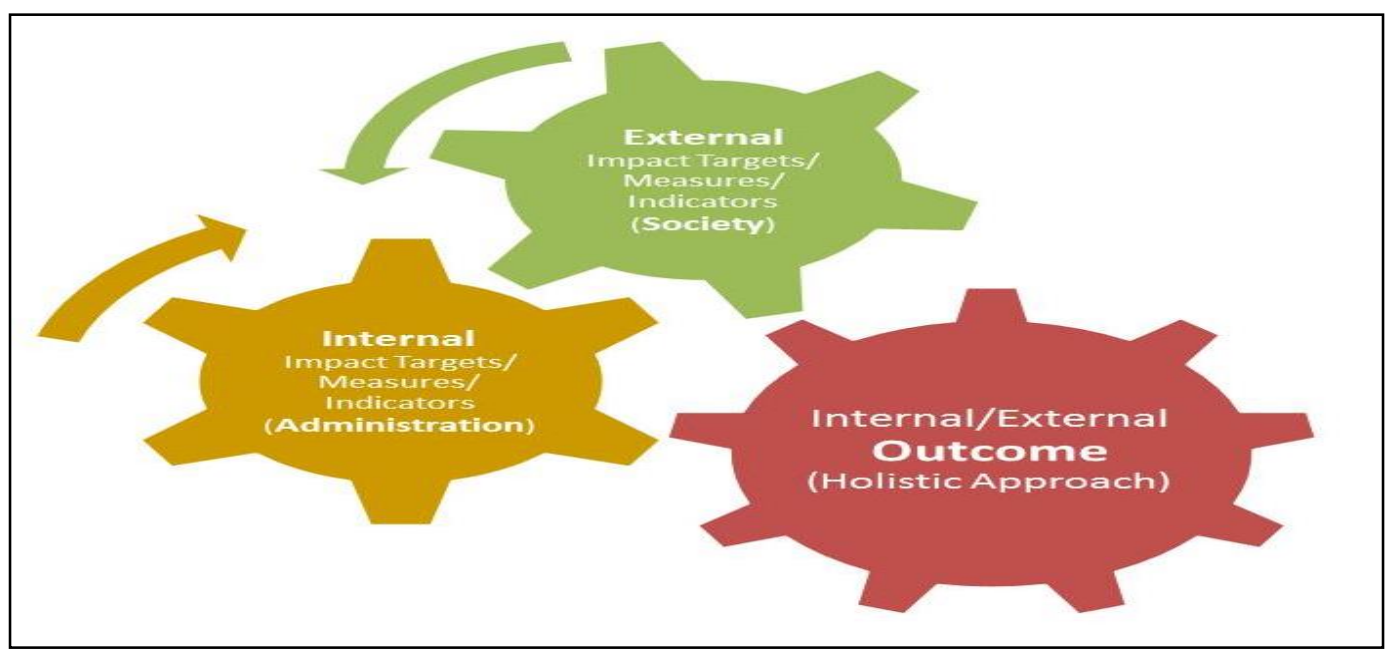

Impact orientation in Austria, therefore, is still an ongoing process which is confronted with a lot of obstacles and resistances. But the new discussion about a second round of reform measures at the Federal level, the declared intention of spreading the concept to the federal states as well as the reciprocal learnings and the exchange between different reform projects are clear signs that the constitutionally 
entrenched path will not be fundamentally altered. By following this direction, Austria is in alignment with other European and developed Non-European states in realizing the overdue renunciation of input-orientation in favor of a modern and more transparent output/outcome-oriented public management - with all the difficulties and objections this will initially encompass. 


\section{Bibliography:}

- Bundeskanzleramt. (2011a). Handbuch Wirkungsorientierte Steuerung. Unser Handeln erzeugt Wirkungen. Wien.

- Bundeskanzleramt. (2011b). Handbuch Ziele und Indikatoren auf Untergliederungs-, Globalbudget- und Detailbudgetebene. Wien.

- Bundeskanzleramt. (2012a). Handbuch Ressortinternes Wirkungscontrolling. Ressorts wirkungsorientiert steuern. Wien.

- Bundeskanzleramt. (2012b). Wirkungsorientierte Budgetunterlagen. Lesehilfe. Wien.

- Bundeskanzleramt. (2013a). Handbuch Wirkungsorientierte Folgenabschätzung. Arbeitsunterlage. Wien.

- Bundeskanzleramt (2013b): Bericht über die wirkungsorientierte Folgenabschätzung. Bericht gemäß § 68 Abs. 5 BHG 2013 iVm $\S \S 6$ und 9 Abs. 2

Wirkungscontrollingverordnung. Wien.

- Bundeskanzleramt. (2013c). Tätigkeitsbericht der ressortübergreifenden Wirkungscontrollingstelle. Bericht gemäß § 68 Abs. 5 BHG 2013 iVm $§ \S 7$ und 9 Abs. 3 Wirkungscontrollingverordnung. Wien.

- Bundeskanzleramt. (2013d). Die Flexibilisierungsklausel. [Available at: https://www.bka.gv.at/site/6359/default.aspx].

- Bundeskanzleramt. (2014a). Wirkungscontrollingstelle des Bundes. [Available at: https://www.oeffentlicherdienst.gv.at/wirkungsorientierte_verwaltung/controllingstelle/i ndex.html].

- Bundeskanzleramt. (2014b). Ziele und Indikatoren. [Available at: https://www.oeffentlicherdienst.gv.at/wirkungsorientierte_verwaltung/steuerung/ziele_in dikatoren/ziele_und_indikatoren.html].

- Bundeskanzleramt. (2014c). Qualitätssicherung. [Available at: https://www.oeffentlicherdienst.gv.at/wirkungsorientierte_verwaltung/steuerung/qualita etssicherung/qs.html].

- Bundeskanzleramt. (2014d). Ressortinternes Wirkungscontrolling. [Available at: https://www.oeffentlicherdienst.gv.at/wirkungsorientierte_verwaltung/steuerung/mit_ziel en_steuern/mit_zielen_steuern.html].

- Bundeskanzleramt. (2014e). Wirkungsorientierte Folgenabschätzung. [Available at: https://www.oeffentlicherdienst.gv.at/wirkungsorientierte_verwaltung/folgenabschaetzun g/index.html]. 
- Bundeskanzleramt. (2014f). Wirkungsdimensionen. [Available at:

https://www.oeffentlicherdienst.gv.at/wirkungsorientierte_verwaltung/folgenabschaetzun g/wirkungsdimensionen/wirkungsdimensionen.html].

- Bundeskanzleramt. (2014g). Interne Evaluierung. [Available at: https://www.oeffentlicherdienst.gv.at/wirkungsorientierte_verwaltung/folgenabschaetzun g/evaluierung/interne_evaluierung.html].

- Bundeskanzleramt. (2014h). Bericht über die wirkungsorientierte Folgenabschätzung. Bericht gemäß § 68 Abs. 5 BHG 2013 iVm $\S \S 6$ und 9 Abs. 1 Wirkungscontrollingverordnung. Wien.

- Bundesministerium für Finanzen. (2008). Implementierung von Wirkungsmessung und Evaluierung ein praktischer Zugang für die Verwaltung [Working Paper 2/2008]. Wien.

- Bundesministerium für Finanzen. (2010a). Handbuch Organisation der Haushaltsführung und Dienstellensteuerung (OHD) ab 2013. Wien.

- Bundesministerium für Finanzen. (2010b). Gender Budgeting - Ein Leitfaden zur Umsetzung der Haushaltsrechtsreform [Working Paper 2/2010]. Wien.

- Bundesministerium für Finanzen. (2011). Wirkungsorientierte Haushaltsführung. Handbuch. Wien.

- Bundesministerium für Finanzen. (2013a). Strategiebericht zum Bundesfinanzrahmengesetz 2014 - 2017. Wien.

- Bundesministerium für Finanzen. (2013b). Bundesfinanzrahmen und Strategiebericht. [Available at: https://www.bmf.gv.at/budget/das-budget/bundesfinanzrahmen-undstrategiebericht.html].

- Bundesministerium für Finanzen. (2014a). Erste Etappe der Haushaltsrechtsreform. [Available at: https://www.bka.gv.at/site/6359/default.aspx].

- Bundesministerium für Finanzen. (2014b). Zweite Etappe der Haushaltsrechtsreform. [Available at: https://www.bmf.gv.at/budget/haushaltsrechtsreform/zweite-etappe-derhaushaltsrechtsreform.html].

- Bundesministerium für Finanzen. (2014c). Detaildokumente 2013. [Available at: https://service.bmf.gv.at/BUDGET/budgets/2013/bfg/teilhefte/_start_teilhefte.htm].

- Federal Chancellery (2012a).Performance Management At the federal level of government in Austria.[Available at https://www.oeffentlicherdienst.gv.at/wirkungsorientierte verwaltung/dokumente/Folde r Wo Steuerung EN.pdf?4ppzwg].

- Federal Chancellery (2012b).Regulatory Impact Assessment and the Impact Dimension of Gender Equality.[Available at 
https://www.oeffentlicherdienst.gv.at/wirkungsorientierte_verwaltung/dokumente/Folde r_Wo_Folgenabschaetzung_EN.pdf?4ppzwg].

- Geppl, Monika \&Seiwald, Johann (2012): Wirkungsorientierte Steuerung: Chancen und Spannungsfelder, in: Das öffentliche Haushaltswesen in Österreich (ÖHW), 53 (1-3), pp. 3852.

- Egger-Peitler, Isabell (2013): Wie Wirkungen den Bund steuern - ein neues Steuerungskonzept für den österreichischen Bund, in: Verwaltung und Management, 19 (2), pp. 82- 89.

- Hammerschmid, Gerhard \& Grünwald, Alexander (2014): Fokusstudie - Einführung der wirkungsorientierten Verwaltungssteuerung. Erfolge - Potentiale - Perspektiven, hrsg. Bundeskanzleramt, Wien.

- Steger, Gerhard (2007): Ziele und Umsetzung der Haushaltsrechtsreform des Bundes, in: Das öffentliche Haushaltswesen (ÖHW), 48 (1-2), pp. 5-9.

- Steger, Gerhard(2009): Die Haushaltsrechtsreform des Bundes, in: Journal für Rechtspolitik (JRP), 17 (1), pp. 23-36.

- Zendron, Silvia (2008). Wirkungsorientierung im öffentlichen Haushalt. Anmerkungen zu einigen kritischen Punkten. Das öffentliche Haushaltswesen in Österreich ÖHW, 49 (3-4), pp. 147-170.

- Zendron, Silvia(2009). Wirkungsorientierung im öffentlichen Haushalt. Anmerkungen zu einigen kritischen Punkten. Managementforum 2009, pp. 39-58. 